\title{
Evaluation of Economic, Energy-environmental and Sociological Effects of Substituting Non-renewable Energy with Renewable Energy Sources
}

\author{
Joachim Koziol ${ }^{1}$, Barbara Mendecka ${ }^{* 2}$ \\ ${ }^{1}$ Institute of Thermal Technology, Silesian University of Technology, Konarskiego 22, Gliwice, Poland \\ e-mail: jkoziol@polsl.pl \\ ${ }^{2}$ Institute of Thermal Technology, Silesian University of Technology, Akadamicka 2A, Gliwice, Poland \\ e-mail: barbara.mendecka@polsl.pl
}

Cite as: Koziol, J., Mendecka, B., Evaluation of Economic, Energy-environmental and Sociological Effects of Substituting Non-renewable Energy with Renewable Energy Sources, J. sustain. dev. energy water environ. syst., 3(4), pp 333-343, 2015, DOI: http://dx.doi.org/10.13044/j.sdewes.2015.03.0025

\begin{abstract}
In this article, to assess the use of renewable energy sources, the method of social efficiency of substituting non-renewable fuels with renewable energy sources was used. Social efficiency means the difference of energy-environmental, economic or sociological effects connected with producing the same amount of usable product in conditions of applying reference fuel and renewable substitute energy source. The amount of useful product should equal the use of one substitute energy unit. The proposed method constitutes a generalization of the existing method of economic effect evaluation on the basis of the Economic Efficiency of Energy Substitution indicators (EEES). Furthermore, the relations of calculations which enable defining dimensionless indexes for the effects of interest and method of standardization of the social efficiency index were described. The procedure is applied for the evaluation of renewable energy sources (solar energy in solar collectors, boilers powered by biofuels and heat pumps using geothermal energy) to prepare hot tap water.
\end{abstract}

\section{KEYWORDS}

Renewable energy sources, Non-renewable energy sources, Economic effects, Energy-environmental effects, Social effects, Energy substitution, Domestic hot water.

\section{INTRODUCTION}

Energy sources are used in the residential sector to fulfil a variety of basic living needs, such as space heating, space cooling, ventilation and air-conditioning, heating tap water, cooking, lighting and electricity for other equipment.

The share of total energy supply in energy conversion systems strictly depends on geographical and geological conditions. According to the data from International Energy Agency [1], the production of energy in the Polish residential sector is based mainly on fossil fuels. The first place belongs to hard coal covering 54\% of the demand. Oil products and natural gas also have a significant share of total energy supply. The shares of oil products and natural gas in the total balance of energy consumption are respectively $25 \%$ and $13 \%$. The total balance is closed by Renewable Energy Sources (RES), mostly biofuels. Using RES can be an important solution to many social problems that the world faces today. The energy needs of a building associated with the production of heat, hot tap water, electricity or the preparation of meals can be satisfied by using different energy sources (especially RES), which causes various social (economic, ecological or

${ }^{*}$ Corresponding author 
sociological) effects. This is why, it is necessary to establish the most favourable conditions for considered useful product generation, especially in terms of household energy systems.

The evaluation of energy conversion systems was usually based on single criteria assessment. The traditional single criterion decision-making approach is no longer able to handle these problems because of the multiplicity of criteria for substituting fossil fuel energy with renewable energy sources, and the involvement of different actors in the decision procedure. In accordance to the literature [2-6], a multi-criteria approach was described which builds on the concept of sustainability and quality of life in terms of energy systems. There are many indicators that can be used to assess the performance of an energy conversion system [2-5]. However, it may be difficult to make decisions, when the multi-criteria model is based on a large number of indicators. For this purpose, the indicator of social efficiency of energy substitution proposed by authors is helpful.

The aim of this article is to draw up a generalized, multi-faceted method for evaluating the social energy substitution efficiency indicator with strong focus on the economic, energy-environmental and sociological effects which refer to the increased use of renewable energy sources.

When evaluating energy sources substitution during useful product generation, it is helpful to define the social effects (costs or benefits) which are important on account of sustainable development and quality of life. The aforementioned social effects may refer to energy, ecology or living conditions. Social efficiency of substitution depends on the adopted evaluation indicators of using specific energy sources. For example, energy indicators may be presented as unit consumption of primary and/or final non-renewable energy and/or primary exergy [7, 8]. Economic indicators may define unit costs accompanying product generation or indicators resulting from the Life Cycle Cost (LCC) analysis [9-11]. Then, ecological indicators may be presented as unit Greenhouse Gases emissions (GHG) [11], Thermo-Ecological Cost (TEC) [7, 8, 11] and/or indicators resulting from the Life Cycle Assessment (LCA) analysis [12-15]. The sociological indicators are the most difficult to assess, which is caused by diversity of these effects and lack of representative data. Furthermore, social effects may be measurable in the case of number of workplaces, or hard-to-measure in terms of ecological, political or economic awareness assessment [16].

\section{GENERIC METHODOLOGY OF CALCULATING THE SOCIAL EFFICIENCY OF ENERGY SUBSTITUTION}

The generic methodology of calculating social efficiency of energy substitution base on the methodology of economic efficiency of energy substitution $[17,18]$.

An indicator of social efficiency of energy substitution is defined as the difference between the $i$-type indicator of $j$-type effect (economic, energy-environmental or sociological) of useful product generation in reference scenario and alternative scenario of useful product generation and it is related to unit of substitutable product (for example substitutable energy). The reference scenario is used as a baseline and assumes that the useful products are generated by fossil fuels. The alternatives consider the renewable energy sources.

Having taken into account, indicators $I$ of Non-renewable fuels $(N R)$ and energy substitution with Renewable energy sources $(R)$ which refers to the alternative type of useful product generation and concerns $j$-type social effect for $i$-type indicator (e.g. LCC, TEC, cumulative $\mathrm{CO}_{2}$ emission, job creation) of social effect may be calculated by means of the following generic formula, where the $n_{i, R}$ is defined by unit number of useful products generated by the energy unit from the substitution source: 


$$
I_{j, R}^{i}=n_{R}\left(e_{j, N R}^{i}-e_{j, R}^{i}\right)
$$

If the useful product is measured by energy units, e.g. heat or electric energy $n_{i, R}$ is dimensionless.

The suggested methodology assumes that it is necessary to retain comparability conditions of the product generation processes: the number of useful products generated with one or the other energy source has to be equal, exploitation periods of the useful product generation systems to be compared should be the same or similar at least, efficiency of the processes compared should be equal or similar at least, location of the processes compared has to be the same. It is advisable that the effect refers to consumption of an energy unit (e.g. $1 \mathrm{GJ}$ or $1 \mathrm{kWh}$ ) from the substitution source.

In some cases, economic policy prevents the sole use of renewable energy sources to generate useful product. Thus, it is necessary to apply auxiliary fuel. Such a problem appears in the case of generating hot tap water by means of solar collectors. At night and with high cloud cover, solar energy is insufficient to produce the amount and quality of water required. Then it is necessary to use auxiliary non-renewable fuels (AD), e.g. natural gas, or auxiliary energy, e.g. electric energy. This should be taken into account while defining the unit number of useful products generated by the energy unit from substitution source $n_{i, R}$. If the useful product of a process refers to use the auxiliary energy, the following relation appears:

$$
n_{R}=\frac{n_{R+A D}}{\varepsilon_{R}}
$$

where $\varepsilon_{R}$ is the share of substitutable energy in total demand and $n_{R+A D}$ is the number of useful products generated by the energy unit from substitution and auxiliary source. When it is necessary to use auxiliary fuel along with the renewable energy analyzed the data available concern social effects of joint use of renewable energy and auxiliary energy. Then, the relation (1) is as follows:

$$
I_{j, R}^{i}=\frac{n_{R+A D}}{\varepsilon_{R}}\left(e_{j, N R}^{i}-e_{j, R+A D}^{i}\right)
$$

where $e_{j, R+A D}^{i}$ is the summary $i$-type indicator of $j$-type social effect of using substitutable and auxiliary energy.

Along the dynamic fluctuations of the absolute value of the considered social effect it is noted that dimensionless parameters of the effects are changing less than the absolute parameter. The dimensionless parameters are determined by the following formulae:

$$
E_{j, R}^{i}=\frac{e_{j, R+A D}^{i}}{e_{j, N R}^{i}}
$$

As a result of the combination of the equations (3) and (4), social efficiency can be calculated as follows:

$$
I_{j, R}^{i}=\left[n_{R}-\left(1-\frac{1}{\varepsilon_{R}}\right) n_{A D}\right]\left[1-E_{j, A D}^{i}-\varepsilon_{R}\left(E_{j, R}^{i}-E_{j, A D}^{i}\right)\right] e_{j, N R}^{i}
$$

The determination of the dimensionless parameters allows specifying social efficiency based only on absolute data concerning the one type of energy conversion namely the reference type. 


\section{SELECTING AND GROUPING THE INDICATORS}

The next step is to select the proper indicators reflecting the different aspects of social efficiency in terms of energy systems. In the case of energy systems, the social indicators have been classified into three groups which refer to the increased use of RES:

- Economic (unit life cycle cost);

- Energy-environmental (unit thermo-ecological cost, unit cumulative $\mathrm{CO}_{2}$ emission);

- Sociological (unit job creation).

The methods of evaluation of the considered indicators have been shown in literature $[7,10,18,19]$ and are not the objective of this article.

\section{STANDARDIZATION OF THE SOCIAL EFFICIENCY INDICATOR}

The analysis of formulae (1), (3) and (5) demonstrates that the efficiency indicators present different dimensions depending on the assessment method of effects. As mentioned before, even the effects of one particular $j$-type may be analyzed in several different ways. The diversity of dimensions hinders comparison of indicators and their averaging. Therefore, assigning an aggregated indicator of societal efficiency must be preceded by a standardization stage of the determined values of effects. The standardized efficiency index $\hat{I}_{j, R}^{i}$ can be calculated using following equation [2]:

$$
\hat{I}_{j, R}^{i}=\frac{\Delta I_{j, R}^{i}}{I_{j, R, \max }^{i}-I_{j, R, \min }^{i}}
$$

For certain indicators (e.g. job creation) an increasing value reflects a positive effect on social efficiency. For other indicators (LCC, TEC, $\mathrm{CO}_{2}$ emission), an increasing value reflects a negative effect on social efficiency. With this in mind the formula $\Delta I_{j, R}^{i}$ depends on the considered indicators and could equal $I_{j, R}^{i}-I_{j, R \text {, min }}^{i}$ if the maximum value of indicator is profitable or $I_{j, R, \max }^{i}-I_{j, R}^{i}$ if minimum value of indicator is profitable.

The proposed standardization method enables to define one non-dimensional value of social efficiency indicators for primary non-renewable fuel substitution with the R-type energy obtained from renewable sources in the case of generating a specific useful product.

It is desirable to calculate a standardized social efficiency index for each group of indicators, taking into consideration the importance of each indicator. Defining the weights $w_{j}$ of indicators appearing in formula (7) and $w_{i j}$ being the weight value of the sub-indicator, they may be established according to the experts' assessment and by means of e.g. the Delphi method [6, 20, 27]:

$$
\hat{I}_{R}=\sum_{j=1}^{L} w_{j} \sum_{i=1}^{M} w_{i j} \hat{I}_{j, R}^{i}
$$

Due to determining the standardized social efficiency values for all considered types of renewable energy sources, it is possible to point out the most beneficial source.

\section{APPLICATION EXAMPLE}

This article presents a method to determine the social efficiency of non-renewable fuels and non-renewable energy substitution with energy from renewable sources. The 
method is exemplified by domestic hot water generation in a municipal building. The analysis included five technologies for hot tap generation. They are presented in Table 1.

The general calculation method comprises the following steps:

- Definition of types of renewable energy utilization;

- Determination of detailed indicator data such as ambient conditions, type, configuration and design of the system;

- Determination of the useful product duration curve and total required energy;

- Determination of the renewable energy sources load duration curve;

- Determination of deficiency and excess of useful product consumption;

- Determination of the peak load from non-renewable or renewable energy;

- Determination of additional data based on generalized formulae;

- Calculation of indicators of social efficiency of non-renewable fuels and non-renewable energy substitution with energy from renewable sources;

- Calculation of standardized indicators of social efficiency of non-renewable fuels and non-renewable energy substitution with energy from renewable sources.

Table 1. Considered technology of domestic hot water production

\begin{tabular}{|c|c|c|c|c|c|c|}
\hline $\begin{array}{l}\text { Supply } \\
\text { system } \\
\text { type }\end{array}$ & $\begin{array}{c}\text { Water } \\
\text { heater type } \\
1\end{array}$ & $\begin{array}{l}\text { Energy } \\
\text { carrier } 1\end{array}$ & $\begin{array}{l}\text { Fraction of } \\
\text { hot water } \\
\text { production }\end{array}$ & $\begin{array}{c}\text { Water heater } \\
\text { type } 2\end{array}$ & $\begin{array}{c}\text { Energy } \\
\text { carrier } \\
2\end{array}$ & $\begin{array}{l}\text { Fraction of } \\
\text { hot water } \\
\text { production }\end{array}$ \\
\hline $\begin{array}{l}\text { Reference } \\
\text { supply } \\
\text { type }\end{array}$ & $\begin{array}{l}\text { Solid fuel } \\
\text { fired } \\
\text { boiler with } \\
\text { retort }\end{array}$ & $\begin{array}{c}\text { Eco pea } \\
\text { coal }[t]\end{array}$ & $100 \%$ & - & - & \\
\hline 2 & $\begin{array}{l}\text { Biomass } \\
\text { boiler }\end{array}$ & $\begin{array}{l}\text { Biomass/ } \\
\text { wood } \\
\text { pellet }[\mathrm{t}]\end{array}$ & $100 \%$ & - & - & - \\
\hline 3 & $\begin{array}{c}\text { Gas fired } \\
\text { condensing } \\
\text { boiler }\end{array}$ & $\begin{array}{l}\text { Natural } \\
\text { gas }\left[\mathrm{m}^{3}\right]\end{array}$ & $40 \%$ & $\begin{array}{c}\text { Thermal } \\
\text { solar system }\end{array}$ & - & $60 \%$ \\
\hline 4 & $\begin{array}{c}\text { Gas fired } \\
\text { condensing } \\
\text { boiler }\end{array}$ & $\begin{array}{l}\text { Natural } \\
\text { gas }\left[\mathrm{m}^{3}\right]\end{array}$ & $40 \%$ & $\begin{array}{l}\text { Thermal solar } \\
\text { system (with } \\
\text { surcharge) }\end{array}$ & - & $60 \%$ \\
\hline 5 & $\begin{array}{c}\text { Ground } \\
\text { heat pump }\end{array}$ & $\begin{array}{l}\text { Electricity- } \\
\text { G11 [kWh] }\end{array}$ & $100 \%$ & - & - & - \\
\hline
\end{tabular}

The assessment of alternative energy systems for covering the hot tap water needs of a building is considered as an application example.

The indicators of social efficiency of non-renewable fuels and non-renewable energy substitution with energy from renewable sources have been defined as the difference between the incurred effect of final effective energy production in the case of primary (reference scenario-NR energy sources) and substitutable (RES) energy application. Domestic Hot Water (DHW) consumption is strongly variable. It depends on the geographical situation, also people's habits, the time of the year, and obviously on the intended purpose of a building. For calculation purposes, the following assumptions were made [21]: a DHW installation supplies the right amount of water to users; DHW production is prioritized in processes of heating water in systems working with central heating boilers; in DHW production systems, there are exchangers and accumulators with 
proper power rating; daily water demand is taken as constant. General principles for designing DHW production systems are presented in articles such as [22].

The energy needed for Domestic Hot Water (DHW) delivered to the user, heat output for DHW systems and capacity of storage tank were calculated using equations contained in [23]. General indicator data for the calculations are shown in Table 2.

Table 2. General boundary conditions

\begin{tabular}{cccc}
\hline Parameters & Symbol & Unit & Value \\
\hline Number of persons & $U$ & - & 5 \\
DHW delivery temperature & $\theta_{W, d e l}$ & {$\left[{ }^{\circ} \mathrm{C}\right]$} & 60 \\
Cold water inlet & $\theta_{W, 0}$ & {$\left[{ }^{\circ} \mathrm{C}\right]$} & 10 \\
\hline
\end{tabular}

The Economic Efficiency of Energy Substitution (EEES) was determined by one effect $e_{E E E S, R}^{1}$ unit LCC. In order to calculate the indicator $I_{E E E S, R}^{1}$ for domestic hot water, the current price data were adopted. The chosen reference method for energy supply was a solution based on a boiler with a retort burner which is fed with the reference fuel - pea coal. The cost of fuels and their low heating values which have been assumed for calculations are shown in Table 3.

Table 3. Cost and heat value of fuel

\begin{tabular}{ccc}
\hline $\begin{array}{c}\text { Fuel, } \\
\text { fuel unit }\end{array}$ & $\begin{array}{c}\text { Unit costs } \\
{[\text { EUR/fuel unit] }}\end{array}$ & $\begin{array}{c}\text { Lower heating value, LHV } \\
{[\text { MJ/fuel unit }]}\end{array}$ \\
\hline Natural gas $\left[\mathrm{m}^{3}\right]$ & 0.32 & 30 \\
Eco pea coal $[\mathrm{t}]$ & 181.16 & 27 \\
Biomass/wood pellet $[\mathrm{t}]$ & 169.08 & 19 \\
Electricity-G11 $[\mathrm{kWh}]$ & 0.12 & - \\
\hline
\end{tabular}

Exemplary values of the Economic Efficiency of Energy Substitution indicators calculated for renewable energy technologies for domestic hot water production are presented in Table 4.

Table 4. Main results of EEES analysis-total cost

\begin{tabular}{cccc}
\hline Supply system type & $\begin{array}{c}E_{E E E S, R}^{1} \\
-\end{array}$ & $\begin{array}{c}e_{E E E S, R}^{1} \\
\text { [EUR per GJ] }\end{array}$ & $\begin{array}{c}I_{E E E S, R}^{1} \\
{[\text { [EUR per GJ } \text { es } \text { ] }}\end{array}$ \\
\hline Ref. & 1.00 & 19.67 & 0.00 \\
2 & 2.04 & 40.12 & -9.14 \\
3 & 0.97 & 19.11 & 4.67 \\
4 & 0.77 & 15.10 & 6.74 \\
5 & 2.14 & 42.05 & -53.89 \\
\hline
\end{tabular}

In the article, the Energy-environmental Efficiency of Energy Substitution (ENES) was determined by two types of effects $e_{E N E S, R}^{1}$ cumulative $\mathrm{CO}_{2}$ emission [28] and $e_{E N E S, R}^{2}$ thermo-ecological cost in life cycle. The formulae of the annual thermo-ecological cost of energy useful product were described in [7]. Exemplary values of the 
Energy-environmental Efficiency of Energy Substitution indicators calculated for renewable energy technologies in the case of domestic hot water production are presented in Table 5 and Table 6.

Table 5. Main results of ENES analysis - $\mathrm{CO}_{2}$ emission $(n=1)$

\begin{tabular}{|c|c|c|c|}
\hline Supply system type & $E_{E N E S, R}^{1}$ & $\begin{array}{c}e_{E N E S, R}^{1} \\
{\left[\mathrm{~kg} \mathrm{CO} \mathrm{CO}_{2} \text { per GJ] }\right.}\end{array}$ & $\begin{array}{c}I_{E N E S, R}^{1} \\
{\left[\mathrm{~kg} \mathrm{CO}_{2} \text { per } \mathrm{GJ}_{\mathrm{es}}\right]}\end{array}$ \\
\hline Ref. & 1.000 & 99.00 & 0.00 \\
\hline 2 & 0.078 & 7.70 & 40.83 \\
\hline 3 & 0.249 & 23.91 & 56.86 \\
\hline 4 & 0.249 & 23.91 & 56.86 \\
\hline 5 & 2.956 & 292.6 & -466.19 \\
\hline
\end{tabular}

Table 6. Main results of ENES analysis - thermo-ecological cost $(n=2)$

\begin{tabular}{cccc}
\hline Supply system type & $\begin{array}{c}E_{E N E S, R}^{2} \\
-\end{array}$ & $\begin{array}{c}e_{E N E S, R}^{2} \\
{[\mathrm{GJ} \text { per GJ] }}\end{array}$ & $\begin{array}{c}I_{E N E S, R}^{2} \\
{\left[\mathrm{GJ} \text { per GJ } \mathrm{es}_{\mathrm{es}}\right]}\end{array}$ \\
\hline Ref. & 1.000 & 1.006 & 0.000 \\
2 & 0.775 & 0.780 & 0.226 \\
3 & 1.382 & 1.390 & 1.006 \\
4 & 1.382 & 1.390 & 1.006 \\
5 & 0.964 & 0.970 & 0.374 \\
\hline
\end{tabular}

Sociological impacts associated with local application of domestic hot water production are very complex and difficult to calculate. The Sociological Efficiency of Energy Substitution (SEES) was determined by the authors as a difference between the creation of workplaces in installing, operating, and maintaining systems of final effective energy production with primary and substitutable (renewable) energy application. Exemplary values of the SEES indicator calculated for renewable energy technologies domestic hot water production are presented in Table 7 [24-26].

Table 7. Main results of SEES analysis-job creation

\begin{tabular}{cccc}
\hline $\begin{array}{c}\text { Supply system } \\
\text { type }\end{array}$ & $E_{S E E S, R}^{1}$ & $\begin{array}{c}e_{S E E S, R}^{1} \\
\text { [person per GJ] }\end{array}$ & $\begin{array}{c}I_{S E E S, R}^{1} \\
\text { [person per GJ } \text { es }^{\text {[ }} \text { ] }\end{array}$ \\
\hline Ref. & 1.000 & 2.34 & 0.000 \\
2 & 1.154 & 2.70 & -0.161 \\
3 & $1.056 / 2.051$ & $2.47 / 4.8$ & -0.130 \\
4 & $1.056 / 2.051$ & $2.47 / 4.8$ & -0.130 \\
5 & 0.132 & 0.31 & 4.888 \\
\hline
\end{tabular}

The dimensionless value of social efficiency indexes for primary non-renewable fuel substitution can be calculated with formulas (6) and (7). In the case of weight values of given criteria, if there are no data or the data are unreliable the Laplace criterion [23] may be applied with the assumption that all particular states are equally likely to occur. However, it is important to take into account that if probability distribution for the weight 
values differs from the uniform distribution the conclusions may be incorrect. Taking into consideration that the selection of the weighting factors is subjective and that there is an unlimited combination of values, it will be assumed here that the relative weight in each group is the same for all the indicators. The values of the main results are provided in Table 8. Results of the aggregated solutions based on the assumption of uniform distribution for weight values are presented in Table 9.

Table 8. Main results of the calculations

\begin{tabular}{|c|c|c|c|c|}
\hline $\begin{array}{l}\text { Supply } \\
\text { system } \\
\text { type }\end{array}$ & $\begin{array}{c}I_{E E E S, R}^{1} \\
{\left[\mathrm{EUR} \text { per } \mathrm{GJ}_{\mathrm{es}}\right]}\end{array}$ & $\begin{array}{c}I_{E N E S, R}^{1} \\
{\left[\mathrm{~kg} \mathrm{CO} 2 \text { per } \mathrm{GJ}_{\mathrm{es}}\right]}\end{array}$ & $\begin{array}{c}I_{E N E S, R}^{2}, \\
{\left[\mathrm{GJ} \text { per } \mathrm{GJ}_{\mathrm{es}}\right]}\end{array}$ & $\begin{array}{c}I_{S E E S, R}^{1} \\
\left.\text { [person per } \mathrm{GJ}_{\mathrm{es}}\right]\end{array}$ \\
\hline Ref. & 0.00 & 0.00 & 0.00 & 0.00 \\
\hline 2 & -9.14 & 40.83 & 0.23 & -0.16 \\
\hline 3 & 4.67 & 56.86 & 1.01 & -0.13 \\
\hline 4 & 6.74 & 56.86 & 1.01 & -0.13 \\
\hline 5 & -53.89 & -466.19 & 0.37 & 4.89 \\
\hline
\end{tabular}

Table 9. Standardized results of the calculations

\begin{tabular}{cccccc}
\hline $\begin{array}{c}\text { Supply } \\
\text { system type }\end{array}$ & $\hat{I}_{R, E E E S}^{i}$ & $\hat{I}_{R, E N E S}^{i, 1}$ & $\hat{I}_{R, E N E S}^{i, 2}$ & $\hat{I}_{R, S E E S}^{i}$ & $\hat{I}_{R}^{i}$ \\
\hline Ref. & 0.889 & 0.891 & 0.000 & 0.968 & 0.768 \\
2 & 0.738 & 0.969 & 0.225 & 1.000 & 0.778 \\
3 & 0.966 & 1.000 & 1.000 & 0.994 & 0.987 \\
4 & 1.000 & 1.000 & 1.000 & 0.994 & 0.998 \\
5 & 0.000 & 0.000 & 0.372 & 0.000 & 0.062 \\
\hline
\end{tabular}

The results of calculations lead to the following comments. If the indicators are taken into consideration individually, then with the economic criteria (unit life cycle cost) the best option is System 4 (thermal solar system with surcharge), while System 5 (ground heat pump) is the most unfavourable. With energy-environmental criterion no 1 (cumulative $\mathrm{CO}_{2}$ emission), the best option are System 4 and 3 (thermal solar system with/without surcharge), while System 5 (ground heat pump) is also the most unfavorable. With the energy-environmental criterion no 2 (thermo ecological cost) the best alternatives are also System 3 and 4, while the most unfavorable is the Reference System (solid fuel fired boiler with retort burner). From sociological point of view, the best option turns out to be System 2 (biomass boiler), while System 5 is also the most unfavorable. If the indicators are compared in a group (standardized social efficiency index), then the order of preference is the same as the energy-environmental criterion no 1 .

\section{CONLUSIONS}

Energy systems play an important role in socioeconomic development especially at the local level. The policy formulation for substituting fossil fuels with renewable energies must be addressed in a multi-criteria context.

In this study, by using generic social efficiency indicator, an integrated decision making approach has been developed and applied for evaluating different technologies 
for hot water generation in the building. Proposed decision making approach is capable of taking into consideration both qualitative and quantitative information. Furthermore, this decision making approach could also be used for solving different problems of the energy carrier selection to cover the energy needs of the building like heating, cooling or power generation.

Using the multi-criteria evaluation procedure proposed by the authors, the performance of an energy conversion system from various points of view can be assessed. Having defined the weights of particular social effects, it is possible to indicate one type of power supply, or different types of power supply but of similar social efficiency. According to the authors, the weights should be defined on the basis of separate analyses, e.g. [24] or defined a priori by the experts. The final decision on values of weights of particular social effects should be made by an investor.

The proposed methodology has been successfully applied for considered decision problem. In future research, similar studies can be conducted based on different multi-criteria decision-making techniques such as fuzzy PROMETHEE, fuzzy ELECTRE or fuzzy TOPSIS for comparative purposes.

\section{NOMENCLATURE}

$\begin{array}{llc}e & \begin{array}{l}\text { absolute effect of energy substitution } \\ \text { dimensionless parameter of effect } \\ E\end{array} & \text { [unit of social indicator/GJ] } \\ I & \begin{array}{l}\text { energy substitution efficiency indicator } \\ \text { normalized energy substitution } \\ \text { indicators efficiency }\end{array} & \text { [unit of social indicator/GJ } \\ \hat{I} & \begin{array}{l}\text { unit quantity of final energy effect related } \\ \text { to unit of reference energy }\end{array} & {[-]} \\ n & \text { number of persons } & {[-]} \\ U & \text { weight of sociological indicator } & {[\text { [person] }} \\ w & & {[-]}\end{array}$

\section{Greek symbols}

$\begin{array}{ll}\Delta & \begin{array}{l}\text { difference } \\ \text { part of substitutable energy in overall energy } \\ \text { consumption }\end{array}\end{array}$

\section{Subscripts and superscripts}

$\begin{array}{ll}i & \text { social indicator evaluation type }(I=1,2, \ldots N) \\ j & \text { type of social effect }(j=1,2, \ldots L) \\ \max & \text { maximal } \\ \min & \text { minimal } \\ \text { es } & \text { substitutable energy }\end{array}$

\section{Abbreviations}

$\begin{array}{ll}\text { AD } & \text { Auxiliary } \\ \text { DHW } & \text { Domestic Hot Water } \\ \text { EEES } & \text { Economic Efficiency of Energy Substitution } \\ \text { ENES } & \text { Energy-environmental Efficiency of Energy Substitution } \\ \text { SEES } & \text { Social Efficiency of Energy Substitution } \\ \text { NR } & \text { Non-renewable Energy } \\ \text { R } & \text { Renewable Energy } \\ \text { W } & \text { Water }\end{array}$




\section{ACKNOWLEDGEMENTS}

This work has been conducted within the Strategic Programme No. PBS-3/RIE-6/2010 supported financially by the National Centre for Research and Development, Poland, 2010-2013.

\section{REFERENCES}

1. http://www.iea.org/statistics, [Accessed: 14-March-2015]

2. Bewszko, T., A multicriteria analysis of energy supply options for municipal and residential customers, Ph.D. Thesis, Rzeszów University of Technology, Rzeszów 2003 (in Polish).

3. Alanne, K., Salo, A., Saari, A. and Gustafsson, S., Multi-criteria evaluation of residential energy supply systems, Energy and Buildings, Vol. 39, Issue 12, pp 1218-1226, 2007, http://dx.doi.org/10.1016/j.enbuild.2007.01.009

4. Mohsen, M. S. and Akash, B. A., Evaluation of Domestic Solar Water Heating System in Jordan using Analytic Hierarchy Process, Energy Conversion and Management, Vol. 38, Issue 18, pp 1815-1822, 1997, http://dx.doi.org/10.1016/S0196-8904(96)00115-X

5. Pokehar, S. D. and Ramachandran, M., Application of Multi-criteria Decision making to Sustainable Energy planning-A review, Renewable and Sustainable Energy Reviews, Vol. 8, Issue 4, pp 365-381, 2004, http://dx.doi.org/10.1016/j.rser.2003.12.007

6. Curtis, I. A., Valuing Ecosystem Goods and Services: A new Approach using a Surrogate Market and the Combination of a Multiple Criteria analysis and a Delphi Panel to assign Weights to the Attributes, Ecological Economics, Vol. 50, Issues 3-4, pp 163-194, 2004, http://dx.doi.org/10.1016/j.ecolecon.2004.02.003

7. Stanek, W., Methodology of Evaluation of Ecological Effects in Thermal Processes with the Application of Exergy Analysis, Silesian University of Technology, Gliwice 2009 (in Polish).

8. Szargut, J. and Stanek, W., Thermo-ecological optimization of a Solar Collector, Energy, Vol. 32, Issue 4, pp 584-590, 2007, http://dx.doi.org/10.1016/j.energy.2006.06.010

9. Kanntola, M. and Saari, A., Renewable vs. Traditional Energy Management Solutions - A Finnish Hospital Facility Case, Renewable Energy, Vol. 57, pp 539-545, 2013, http://dx.doi.org/10.1016/j.renene.2013.02.023

10. Uygunoğlua, T., LCC Analysis for Energy-saving in Residential Buildings with different types of Construction Masonry Blocks, Energy and Buildings, Vol. 43, Issue 9, pp 2077-2085, 2011, http://dx.doi.org/10.1016/j.enbuild.2011.04.011

11. Vivek, R., Life Cycle Cost analysis of HPVT Air Collector under different Indian Climatic Conditions, Energy Policy, Vol. 36, Issue 2, pp 603-611, 2008, http://dx.doi.org/10.1016/j.enpol.2007.08.031

12. Nitkiewicz, A., Energy-environmental analysis of the Performance of Low-temperature District Heating System with Geothermal Heat Pump, Ph.D. Thesis, Częstochowa University of Technology, Częstochowa 2012 (in Polish).

13. Fulvio, A., Beccali, G., Cellura, M. and Lo Brano, V., Life Cycle assessment of a Solar Thermal Collector, Renewable Energy, Vol. 30, Issue 7, pp 1031-1054, 2005, http://dx.doi.org/10.1016/j.renene.2004.09.009

14. Battisti, R., Corrado, A., Environmental assessment of Solar Thermal Collectors with integrated Water Storage, Journal of Cleaner Production, Vol. 13, Issues 1314, pp 1295-1300, 2005, http://dx.doi.org/10.1016/j.jclepro.2005.05.007 
15. Bribián, I. Z., Usón, A. A. and Scarpellini, S., Life Cycle assessment in Buildings: State-of-the-art and Simplified LCA, Building and Environment, Vol. 44, Issue 12, pp 2510-2520, 2009, http://dx.doi.org/10.1016/j.buildenv.2009.05.001

16. Ragwitz, M. et al., EmployRES, F. R., The Impact of Renewable Energy Policy on Economic Growth and Employment in the European Union, European Commission, DG Energy and Transport, April, 2009.

17. Kozioł, J., The Method of evaluation of Fuels Substitution in Process of its utilization, Archives of Energetics, Vol. 4, pp 241-249, 1981 (in Polish).

18. Kozioł, J. and Mendecka, B., An Exemplary Application of the Marginal Costs of Energy Substitution analysis, Archives of Energetics, Vol. 42, Issue 3-4, pp 85-93, 2012.

19. Kozioł, J. and Mendecka, B., The Economic efficiency of Energy substitution for municipal and living application in the low-density Housing District, Poznań, ICT 2011.

20. Wang, J., Jing, Y. and Zhan, C., Weighting Methodologies in Multi-criteria evaluations of Combined Heat and Power Systems, International Journal of Energy Research, Vol. 33, Issue 12, pp 1032-1037, 2009, http://dx.doi.org/10.1002/er.1527

21. Recknagel, H., Sprenger, E. and Schramek, E., Pocketbook for Heating and Air Conditioning 08/09, Munchen: Oldenbourg Industrieverlag, 2008 (in German).

22. Bartnicki, G. and Nowak, B., Designing of the Hot Water Systems, District Heating, Heating, Ventilation, Vol. 3, pp 11-16, 2004 (in Polish).

23. Czubala, J., Influence of Fuel Feeding Strategy for Steam Boilers on CO2 Emission trade Effectiveness considering an example CHP Plant, Ph.D. Thesis, Silesian University of Technology, Gliwice, 2008 (in Polish).

24. Ragwitz, M. et al., EmployRES, F. R., The Impact of Renewable Energy Policy on Economic Growth and Employment in the European Union, European Commission, DG Energy and Transport, April, 2009.

25. Alvarez, G. C., Study of the Effect on Employment of Public Aid to Renewable Energy Sources, Instituto Juan de Mariana, 2009.

26. Moreno, B. and Jesús López, A., The Effect of Renewable Energy on Employment, The Case of Asturias (Spain), Renewable and Sustainable Energy Reviews, Vol. 12, Issue 3, pp 732-751, 2008, http://dx.doi.org/10.1016/j.rser.2006.10.011

27. Greening, B. and Azapagic, A., Domestic Heat Pumps: Life Cycle Environmental Impacts and Potential, Energy, Vol. 39, Issue 1, pp 205-217, 2013, http://dx.doi.org/10.1016/j.energy.2012.01.028

28. Jankowski, A., Energy - Environmental Model for the Forecasting the Energy Consumer Preferences, Ph.D. Thesis, Central Mining Institute, Katowice 2007 (in Polish). 